\title{
Study of Inequality in Providing Clean Water Access in Malang and Pandeglang Districts
}

\author{
Husna Yuni Wulansari, Tadzkia Nurshafira and Taradhinta Suryandari ${ }^{1}$ \\ Universitas Gadjah Mada - Indonesia
}

\begin{abstract}
This paper seeks to analyse the disparity of clean water access fulfillment in Malang district and Pandeglang district. This issue is important due to two considerations. First, Indonesia's National Medium-term Development Plan (RPJMN) 20152019 targets universal access to water and sanitation by 2019 , yet it is still $71,14 \%$ fulfilled in 2016. Second, existing studies on this issue addressed the problem by using technical approach; limited finance and infrastructure, demographic and topographic condition. Such technical aspects are indeed important, however it tends to obscure political dimension, i.e. power relations and social structure dynamics that influence policies regarding access to water. Therefore, this paper will analyse the political dimension of the disparity in clean water access fulfillment. In analysing the problem, this paper will use discourse analysis (Laclau and Mouffe, 2001). This paper analyses the struggle among discourses in fixing the meaning of 'access' as a contested political arena. It will also identify the strategy of various actors in articulating their discourses through the establishment of a network of alliance that can accommodate different interests. This paper aims to be the basis of decision making process that considers and emancipates the difficult circumstances that society are facing and alternative discourse that they have.
\end{abstract}

Keywords: inequality; disparity; clean water access

${ }^{1}$ Husna Yuni Wulansari, Tadzkia Nurshafira and Taradhinta Suryandari, Mahasiswa Fisipol Universitas Gadjah Mada Indonesia, Email: husnayuniw@gmail.com 


\section{Studi Ketimpangan Penyediaan Akses Air Bersih di Kabupaten Malang dan Pandeglang}

Husna Yuni Wulansari, Tadzkia Nurshafira, dan Taradhinta Suryandari

\section{Latar Belakang}

\subsection{Latar belakang}

Air bersih dan sanitasi merupakan salah sektor yang menjadi fokus pemerintah Indonesia dalam RPJMN 2015-2019. Pada sektor ini, pemerintah menetapkan target 100-0-100, yakni 100\% akses air minum, $0 \%$ pemukiman kumuh dan $100 \%$ sanitasilayak. Dengan waktu kuranglebih satu tahun lagi untuk mencapai target tersebut, pertanyaannya kemudian adalah sampai di mana pencapaian pemerintah Indonesia? Berdasarkan Evaluasi Paruh Waktu RPJMN 2015-2019 (Bappenas, 2017), tingkat akses air minum memang selalu naik dari tahun ke tahun. Namun kenaikan rata-ratanya hanya sebanyak 1,5 poin selama periode 2014-2016. Dengan angka akses air minum yang baru mencapai 71,14 pada tahun 2016, artinya masih diperlukan banyak hal untuk mempercepat usaha pencapaian target 100\% akses air minum pada tahun 2019.

Belum terpenuhinya akses air minum masyarakat tidak hanya dapat dilihat dari angkanya di tingkat nasional. Secara empiris, di level kabupaten/kota pun juga terdapat ketimpangan terhadap pemenuhan akses air bersih. Di Kabupaten Malang misalnya, wilayah yang terletak dekat dengan sumber, termasuk wilayah perkotaan, bisa mendapatkan akses air bersih dengan mudah dan harga yang relatif murah melalui layanan PDAM maupun pengusahaan swadaya seperti Water and Sanitation for Low Income Communities (WSLIC) dan Penyediaan Air Minum dan Sanitasi berbasis Masyarakat (PAMSIMAS). WSLIC dan PAMSIMAS merupakan program nasional pemerintah Indonesia terkhusus Kementrian Kesehatan (untuk WSLIC) dan Kementrian Pekerjaan Umum dan Perumahan Rakyat (untuk PAMSIMAS) bersama Bank Dunia yang dimaksudkan untuk menyelenggarakan pengusahaan air bersih berbasis masyarakat. WSLIC terdiri dari dua periode, yakni WSLIC 1 (1994-1999), WSLIC 2 (2003-2007) (Robinson 2005). WSLIC mensyaratkan sumbangan dari masyarakat berupa $16 \%$ in kind (tenaga kerja) dan $4 \%$ in cash (sumbangan dana), dan sisa $80 \%$ akan didanai oleh APBN/APBD. PAMSIMAS sendiri sering disebut sebagai WSLIC 3 dengan perbedaan terletak pada adanya tambahan sumbangan desa sebesar 10\% sehingga yang didanai oleh APBN/APBD sebesar 70\%. Selain itu 
juga terdapat bimbingan dari fasilitator yang lebih lama, yakni hingga target universal access pada 2019, untuk kemudian masyarakat dilepas sendiri (Djauhari, 2018).

Sementara itu, wilayah perdesaan, terlebih yang letaknya jauh dari sumber, akses air bersih menjadi sulit. Masyarakat di wilayah ini, baik dari kelas sosial ekonomi menengah ke atas atau rendah, harus membeli air dengan harga yang relatif mahal. Dengan masih jauhnya angka pemenuhan akses air minum eksisting dari target yang dicapai, dan ketimpangan akses yang terjadi di dalam kabupaten/kota, penelitian ini kemudian berusaha mencari penyebab terjadinya kondisi tersebut.

Di Indonesia, belum banyak penelitian yang mencoba memahami ketimpangan akses air bersih. Penelitian yang sudah ada kebanyakan menjawab pertanyaan tersebut dengan pendekatan teknis seperti kepadatan penduduk, ketersediaan dana/ investasi sarana prasarana untuk menangani kondisi geografis Indonesia yang beragam (Noviyanti dan Setiawan, 2014; Sukartini dan Saleh: 2016), kemampuan manajerial dan rendahnya SDM pengelola air bersih (Soebagyo, et al., 2013; Unicef, 2012), serta rendahnya tarif air yang berdampak pada pengembangan layanan (Utama, 2010). Penelitian dengan pendekatan sosial memiliki jumlah yang lebih sedikit dari penelitian dengan pendekatan teknis dan cenderung mengabaikan faktor politis. Menurut Masduqi, Endah, Soedjono dan Hadi, kemiskinan dan kesadaran masyarakat akan kebersihan (Masduqi, et al., 2007; Unicef, 2012) menjadi faktor penjelas dominan yang melatarbelakangi kurangnya akses air bersih masyarakat. Selain itu, dalam tulisan yang sama, Masduqi, Endah, Soedjono dan Hadi juga menggarisbawahi mengenai jenis proyek berbasis masyarakat juga mempengaruhi angka pencapaian pelayanan air minum. Permasalahan dengan penelitian yang sudah ada mengenai pemenuhan akses air bersih adalah diabaikannya dimensi politis yang mungkin melatarbelakangi munculnya faktor-faktor tersebut. Akibatnya, penelitian-penelitian tersebut cenderung meniadakan agensi aktor-aktor atau pemegang kepentingan dalam mencapai kepentingannya terkait akses air bersih. Ketidakpekaan pada sisi politis inilah yang mungkin juga menyebabkan fokus penelitian yang lebih besar ke penyedia air bersih dan menganggap pengguna (atau mereka yang seharusnya berhak mendapatkan air bersih) sebagai pihak yang pasif yang tidak berdaya.

\subsection{Rumusan Masalah}

Penelitian ini akan mencoba menjawab ketimpangan akses air bersih menggunakan pendekatan yang lebih politis, yang diharapkan dapat lebih peka 
terhadap relasi kuasa dan kepentingan dari tiap-tiap pihak yang terlibat dalam pemenuhan akses air bersih. Penelitian ini akan melihat permasalahan teknis yang seringkali dibicarakan oleh pihak-pihak yang ada di level diskursus dengan analisis yang ditawarkan oleh Ernesto Laclau dan Chantal Mouffe (1985). Menggunakan analisis diskursus, 'akses' dapat dipahami sebagai arena yang secara aktif dipertarungkan oleh pihak-pihak yang terlibat dalam isu ini untuk memperjuangkan kepentingan mereka masing-masing. Sehingga agensi dari pihak-pihak yang ada dalam isu ini tidak lagi dikaburkan. Data untuk analisis diskursus didapatkan melalui observasi, wawancara dengan berbagai pihak dalam pemenuhan akses air bersih, dan juga pembacaan data sekunder dari berbagai dokumen milik pemerintah, organisasi internasional, LSM, dan juga berita daring.

Data dikumpulkan dari dua kabupaten yakni Kabupaten Malang dan Pandeglang. Terdapat tiga alasan pemilihan kedua kabupaten tersebut. Pertama, kedua kabupaten tersebut dipilih sebagai perbandingan berdasarkan topografi dan variasi penyedia layanan air minum yang relatif sama. Kedua kabupaten tersebut merupakan kabupaten dengan luas wilayah terbesar kedua di masing-masing propinsi, yakni Jawa Timur dan Banten (BPS Jawa Timur, 2017; BPS Banten, 2018). Malang dan Pandeglang sama-sama memiliki variasi topografi yang hampir sama, yakni sama-sama terdiri dari dataran tinggi dan pesisir. Variasi kondisi topografi ini menjadi penting untuk memberikan konteks spasial pada kontestasi diskursus, di mana distribusi air lekat dengan kondisi geografis di wilayah tersebut. Selain itu, kedua daerah juga masuk 3 terbesar penerima PAMSIMAS di masing-masing provinsi di tahun 2017 (Kementrian Kesehatan, 2017). Sehingga, paling tidak sudah terdapat dua variasi penyedia air minum yang dominan yakni PDAM dan PAMSIMAS. Kedua, meskipun terdapat kesamaan, yang membuat kedua daerah tersebut menarik adalah perbedaan capaian akses air minum. Berdasarkan data Susenas terkait Akses Air Minum Kabupaten Kota 2016, Kabupaten Malang menempati posisi tengah dengan angka 65,98\%, sementara Pandeglang merupakan kabupaten dengan akses terburuk kedua di Jawa dengan angka 40,01\%. Ketiga, konteks Jawa dipilih karena meski terletak di Jawa yang merupakan pusat pembangunan, ketimpangan akses yang terjadi juga dapat menjadi gambaran konteks pembangunan yang tidak merata yang terjadi di luar kawasan Jabodetabek.

Tulisan ini berargumen bahwa ketimpangan akses air bersih terjadi karena adanya kontestasi diskursus mengenai respons terhadap keterbatasan geografis yang 
mengakibatkan terbatasnya akses terhadap air bersih.

\subsection{Landasan Konseptual}

Tulisan ini akan menggunakan analisis diskursus (Laclau dan Mouffe, 1985). Secara umum, analisis diskursus berupaya menganalisis bagaimana praktik-praktik sosial mengartikulasikan dan mengontestasikan diskursus yang membentuk realitas sosial. Pada titik ini, diskursus merupakan sebuah jalinan ide, praktik dan aksi yang secara parsial menetapkan makna sebuah objek dan menjadikannya hegemonik. Hal ini membuat objek tersebut dinormalisasi dengan cara tertentu, serta menyaratkan adanya eksklusi terhadap cara pandang alternatif.

Secara khusus, asumsi dasar yang diajukan oleh Laclau dan Mouffe (1985:7) adalah bahwa seluruh fenomena sosial tidak akan pernah bisa 'selesai' atau totalmakna dari suatu fenomena selalu berada dalam ketidakpastian dan menyisakan ruang-ruang kontestasi diskursif yang selalu diisi oleh pertarungan dari berbagai kekuatan sosial dalam masyarakat. Upaya yang konstan dan terus menerus untuk mengisi makna dari suatu fenomena ini adalah titik masuk bagi analisis diskursus. Analisis ini bertujuan untuk memetakan proses politik dari fiksasi makna dan upayaupaya untuk membuatnya tampak alamiah. Proses ini, dalam bahasa Laclau dan Mouffe, disebut sebagai praktik artikulasi, sedangkan sebuah totalitas terstruktur, atau pemaknaan, yang dihasilkan dari praktik tersebut adalah diskursus (Laclau dan Mouffe, 1985:105). Dalam artilain, diskursus dapat dipahami sebagai penetapan secara parsial sebuah makna yang dilakukan dalam upaya mengonstruksi sebuah 'nodal points'. Karena itu, hegemoni merupakan praktek artikulasi yang membangun 'nodal points' (titik temu) yang memperbaiki makna sosial dalam sebuah sistem secara parsial.

Penetapan parsial atas sebuah makna dalam diskursus hanya dapat dilakukan dengan mengeliminasi berbagai kemungkinan pemaknaan alternatif yang dimiliki oleh sebuah tanda. Hal ini dilakukan untuk menghentikan berbagai macam ambiguitas dan untuk memproduksi kesatuan sistem pemaknaan yang koheren (Jorgensen dan Phillips, 2002:27). Kemungkinan-kemungkinan yang dieliminasi ada di dalam sebuah bidang diskursif (field of discursivity) yang mengakomodasi berbagai surplus pemaknaan yang dihasilkan dan dieksklusi dalam praktik artikulasi. Karenanya, sebuah diskursus selalu dikonstitusi oleh alternatif yang dieksklusi, oleh bidang diskursifnya (Laclau dan Mouffe, 1985:111-113). Diskursus merepresentasikan momen ketika penanda mengambang (floating signifier), sebuah 
tanda yang merepresentasikan ruang dengan surplus dan pluralitas pemaknaan, ditetapkan maknanya secara parsial.

Di sisi lain, hal ini menekankan sisi antagonisme dari 'the political' yang diajukan oleh Mouffe (2005) - sebuah entitas hanya akan mendapatkan makna dan identitasnya sejauh ada yang liyan, 'others' yang konfliktual, namun bersifat konstitutif bagi keberadaan identitas tersebut. Dalam arti lain, ia bersifat relasional: hanya dengan keberadaan 'mereka,' 'kami' menjadi relevan dan mendapatkan eksistensinya.

Diskursus bersifat contingent dan adalah produk dari sebuah konstruksi historis yang pemaknaannya akan selalu rentan terhadap kekuatan politik yang dieksklusi dari produksi makna di awal, dan juga adalah akibat-akibat dari dislokasi peristiwa yang tidak dapat dikontrol (Laclau, 1990:35). Dalam hal ini, dislokasi dapat diartikan sebagai celah tempat kontestasi diskursus terjadi-ia, di satu sisi mengancam pemaknaan yang hegemonik, dan di sisi lain merupakan landasan di mana pemaknaan hegemonik dibentuk (Laclau, 1990:37). Dislokasi merusak diskursus dan menimbulkan kelemahan dalam pemaknaan yang dapat mendorong terbentuknya konstruksi diskursif baru untuk menambal struktur yang terdislokasi-ia adalah subversi pada diskursus hegemonik oleh peristiwa yang tidak berhasil disimbolisasikan atau diintegrasikan ke dalam diskursus tersebut. Hal ini berkaitan dengan asumsi dasar lain Laclau dan Mouffe bahwa 'Hegemoni adalah respons atas sebuah krisis', (Laclau dan Mouffe, 1985:7). Dalam konteks ini, dislokasi merepresentasikan 'krisis' sebagai pondasi bagi hegemoni, serta dasar bagi perubahan politik dan pembentukan diskursus yang baru.

Upaya untuk merespons krisis, yakni dengan mengisi makna atas sebuah fenomena melalui pembentukan diskursus, dipahami sebagai proyek hegemoni yang dilakukan oleh kekuatan-kekuatan politik dalam sebuah political frontier. Proyek hegemoni berupaya memenangkan pertarungan hegemoni untuk menjadi penanda utama dari sebuah pemaknaan. Ia tersusun dari berbagai posisi subjek (subject position) yang terbentuk dari tuntutan-tuntutan beragam dan partikular yang sulit untuk dipenuhi ketika berdiri sendiri. Pada titik ini, proyek hegemoni hanya dapat terjadi ketika kelompok-kelompok politik yang ada dalam masyarakat mampu menjalin tuntutan-tuntutan partikular tersebut ke dalam sebuah solidaritas: menjadikan tuntutan yang partikular sebagai universal dan kolektif (Laclau dan Mouffe, 1985:63). Laclau dan Mouffe menyebut jejaring solidaritas ini sebagai rantai ekuivalensi (chain of equivalence). Proyek hegemoni tidak dapat terjadi jika 
rantai ekuivalensi tidak dapat terbentuk: ia hanya berhasil ketika tuntutan-tuntutan partikular yang terfragmentasi, atau posisi subjek yang beragam, dapat dijalin dalam solidaritas untuk membentuk sebuah pemaknaan dan identitas kolektif yang baru (Hiariej, 2017:130).

Perlu untuk menekankan posisi dari empty signifier. Berbeda dengan floating signifier, empty signifier datang dari ketidakmungkinan struktural dari penandaan. Hal ini dikarenakan hegemoni merepresentasikan ketiadaan, atau absen, dari sebuah totalitas (Laclau dan Mouffe, 1985:7). Setiap proyek hegemoni menekankan karakter 'keterbukaan' dari yang sosial—dalam sistem yang tertutup, praktik artikulasi tidak dapat terjadi dan hegemoni tidak akan pernah ada. Empty signifier adalah dasar yang memberikan kemungkinan-kemungkinan dalam setiap bentuk pemaknaan.

Dengan menekankan sisi antagonisme dari politik dan upaya konstan atas pemaknaan, tulisan ini menggarisbawahi hegemoni sebagai proyek yang tidak pernah utuh dan selalu rentan dari kekuatan-kekuatan kontra-hegemoni yang berupaya dieksklusinya. Karenanya, tulisan ini berupaya memahami pemenuhan akses sebagai persoalan perimbangan kekuatan antara kelompok-kelompok sosial dalam masyarakat yang tarik menarik dalam melakukan proyek hegemoni: antara mereka yang berupaya melakukan hegemoni dan melawan hegemoni dengan mengajukan narasi-narasi alternatif terkait akses. Tulisan ini akan melakukan analisis terhadap praktik-praktik sosial yang mendorong pemaknaan hegemonik atas akses berikut dengan kondisi dari pemaknaan alternatif yang melakukan proyek hegemoni tandingan untuk mendapatkan akses mereka terhadap air bersih.

\section{Pembahasan}

\subsection{Kondisi Umum}

\subsubsection{Pandeglang}

Pandeglang adalah salah satu kabupaten yang terletak di sebelah barat Provinsi Banten dengan luas $2.747 \mathrm{~km}^{2}$. Sejak 2011, Kabupaten Pandeglang dibagi menjadi 35 kecamatan dan 339 desa. Data Badan Pusat Statistik (BPS) Kabupaten Pandeglang (2015) menunjukkan bahwa jumlah populasi di kabupaten tersebut mencapai 1.194.911 jiwa. Dengan jumlah penduduk lokal sebanyak 440.839 yang bekerja, 42.96\% memiliki mata pencaharian pada sektor pertanian. Sektor lain yang memberikan kontribusi cukup signifikan pada mata pencaharian yakni perdagangan, hotel dan restoran (16.47\%), jasa (15.79\%), dan industri manufaktur (7.41\%). 
Perkembangan terus-menerus Kabupaten Pandeglang meningkatkan adanya kebutuhan untuk memenuhi kebutuhan pelayanan dasar dan penunjang, salah satunya air bersih. Menurut data dari BPS Kabupaten Pandeglang, presentasi konsumen air minum di PDAM Pandeglang tahun 2015 mencakup 92\% untuk tempat tinggal, $4 \%$ untuk perusahaan, perdagangan dan industri, serta $2 \%$ masingmasing untuk masjid dan instansi pemerintah (BPS Kabupaten Pandeglang, 2017:323). Di sisi lain, data yang disampaikan oleh PDAM (2018) menunjukkan bahwa jumlah pelanggan PDAM kurang lebih 19.200 Sambungan Rumah (SR) yang dibagi ke dalam dua cabang, yakni Cabang Pandeglang dan Cabang Labuan, serta tiga unit Ibu Kota Kecamatan (IKK), yakni Unit IKK Menes, Unit IKK Panimbang, dan Unit IKK Sobang. Pendistribusian air dilakukan dalam tiga sistem, yakni gravitasi (70\%) yang mengambil langsung dari sumber mata air, 25\% perpompaan, dan $5 \%$ pengolahan lengkap. Sistem pengelolaan lengkap dilakukan melalui pengolahan air keruh dan didistribusikan pada warga setelah jernih.

Perubahan pada Kabupaten Pandeglang dapat mempengaruhi potensi atau ketersediaan air baku, baik berasal dari sumber air permukaan, cekungan air tanah dan air hujan yang memenuhi baku mutu sebagai air baku untuk minum (Dinas Perumahan Kawasan Permukiman dan Pertanahan Kabupaten Pandeglang dan Lembaga Penelitian dan Pengabdian kepada Masyarakat Institut Teknologi Bandung, 2017:1). Perbedaan karakteristik fisik dasar di tiap wilayah Pandeglang membuat keberadaan dan potensi air baku berbeda-beda-beberapa memiliki sumber melimpah dan beberapa kekurangan atau bahkan tidak memiliki sumber air baku.

Kondisi ini membuat ketimpangan distribusi akses air yang tidak merata: daerah utara yang didominasi oleh perkotaan dilimpahi potensi air baku, bahkan hingga terbuang percuma, sedangkan daerah Selatan yang didominasi pedesaan kekurangan air. Limpahan air dari daerah utara belum dapat didistribusikan dengan baik ke daerah-daerah bagian lain. Perusahaan Daerah Air Minum (PDAM) Kab. Pandeglang menyatakan bahwa cakupan pelayanan untuk seluruh penduduk di wilayah administrasi Kab. Pandeglang baru masih rendah karena baru mencapai 9.8\% (PDAM Kabupaten Pandeglang, 2018). Salah satu sumber mata air yang digunakan dengan prinsip gravitasi, yakni mata air Cikoromoy, memiliki potensi sekitar 450 liter per-detik. Meski demikian, PDAM hanya bisa memanfaatkan 42 liter-sekitar 10\% dari keseluruhan jumlah potensi yang ada. Jumlah ini juga baru mencakup 18 dari 35 kecamatan, dan dalam satu kecamatan tidak seluruh desa dilayani (PDAM 
Kabupaten Pandeglang, 2018). Beberapa sumber air non-PDAM yang digunakan dalam memenuhi air bersih yakni mata air di dalam tanah dan sumur bor-dua mekanisme yang memerlukan anggaran cukup besar untuk penggunaannya.

\subsubsection{Malang}

Kabupaten Malang merupakan kabupaten dengan luas wilayah kedua terluas di Jawa Timur dengan luas wilayah 2.977,05 $\mathrm{km}^{2}$. Wilayah ini memiliki 2.560.675 penduduk, sehingga Kabupaten Malang memiliki kepadatan penduduk sebanyak $86,14 / \mathrm{km}^{2}$ (BPS Kabupaten Malang, 2017). Wilayahnya yang terletak di bagian tengah selatan propinsi Jawa Timur memiliki kontur geografis yang terdiri dari dataran rendah, termasuk wilayah pesisir pantai, dan dataran tinggi dengan 9 gunung dan 1 pegunungan (BPS Kabupaten Malang, 2017). Dengan kontur geografis yang demikian, Kabupaten Malang mampu memiliki akses air bersih yang cukup baik. Secara total, berdasarkan data yang dihimpun oleh PDAM Kabupaten Malang (2018), per Oktober 2017, cakupan pelayanan air bersih di Kabupaten Malang sudah mencapai 92,49\% (data per Oktober 2017) yang terdiri dari 39,90\% yang dipenuhi oleh Himpunan Penduduk Pengguna Air Minum (HIPPAM), 32,21\% oleh PDAM, dan 20,28\% oleh penyediaan air non-perpipaan seperti sumur gali dan sumur pompa tangan. 7,51\% yang belum tercakup penyedia layanan air bersih merupakan daerah rawan air yang tersebar di 9 kecamatan di Kabupaten Malang bagian selatan. Daerah yang terletak di dataran tinggi biasanya memiliki sumber air yang berasal dari mata air, tetapi karena letak sumber yang berada lebih rendah dari pemukiman, memerlukan teknologi perpompaan untuk membawa air ke pemukiman penduduk. Namun, ada pula pengusahaan air melalui metode gravitasi. Masyarakat di daerah ini biasanya mengusahakan penyediaan air bersih melalui swadaya, baik melalui skema WSLIC, PAMSIMAS, atau skema swadaya yang lain dan juga PDAM, jika daerah tersebut masuk dalam daerah perkotaan (Sidharta, 2018). Program WSLIC dan PAMSIMAS membutuhkan penjelasan lebih lanjut mengingat banyaknya jumlah pelanggan program ini di Kabupaten Malang yang bahkan melebihi jumlah pelanggan PDAM. Kabupaten Malang merupakan Kabupaten yang mengikuti program penyediaan air berbasis masyarakat sejak WSLIC 2 hingga PAMSIMAS (Sidharta, 2018). Kedua program nasional penyediaan air berbasis masyarakat tersebut dibawahi oleh Dinas Perumahan, Kawasan Permukiman, dan Cipta Karya (DPKPCK Kabupaten Malang, 2018). Sementara pemetaan desa yang memerlukan program PAMSIMAS dilakukan 
oleh Panitia Kemitraan (Pakem) yang terdiri dari Bappeda, Dinas Kesehatan, Dinas Pendidikan, PDAM, Asosiasi HIPPAM, Dinas Pemberdayaan, dan Dinas Pekerjaan Umum Sumber Daya Air (PU SDA) (Djauhari, 2018). WSLIC, PAMSIMAS, dan program swadaya lain di Kabupaten Malang kemudian biasa disebut sebagai HIPPAM.

Sementara itu, daerah Malang bagian selatan yang kebanyakan terdiri dari wilayah pantai, tidak memiliki sumber mata air dan harus mengandalkan sumur bor dalam yang memerlukan biaya yang tidak murah. Sulitnya air inilah yang menjelaskan mengapa wilayah ini merupakan wilayah yang paling sedikit dilayani oleh PDAM Kabupaten Malang (Wijaya, 2018). Masyarakat biasanya kemudian mengandalkan pembelian air bersih yang disediakan oleh swasta dalam bentuk tangki atau drum dengan harga yang lebih mahal daripada air disediakan dari PDAM maupun swadaya di wilayah lain. Pada musim kemarau, dinas-dinas terkait seperti DPKPCK, Dinas Lingkungan Hidup, Badan Penanggulangan Bencana Daerah, Palang Merah Indonesia (PMI), dan PDAM juga mengirimkan bantuan air tangki ke wilayah ini (PDAM Kabupaten Pandeglang, 2018).

\subsection{Pemetaan Aktor dan Persepsi terhadap Persoalan Akses}

\subsubsection{Pandeglang}

Dalam pengelolaan sumber daya air di Kab. Pandeglang, terdapat beberapa aktor yang terlibat. Tiga pemangku kepentingan utama adalah pemerintah, masyarakat, dan sektor privat. Dari temuan tim penulis, sektor pemerintah yang terlibat dalam pengelolaan air terdiri dari PDAM, Bappeda, Dinas Pemberdayaan Masyarakat dan Pemerintahan Desa (DPMPD), Dinas Perumahan, Kawasan Permukiman dan Pertanahan (DPKPP), Dinas Kesehatan, Tim Fasilitator Penyediaan Air Minum dan Sanitasi Berbasis Masyarakat (PAMSIMAS), dan pemerintahan desa. Sektor privat yang terlibat terdiri dari beberapa penyedia air di level dusun dan pemilik tangki yang mendistribusikan air bersih ke depot air minum. Masyarakat sipil yang terlibat meliputi warga-warga yang tinggal di daerah perkotaan dan pedesaan, yakni Desa Girijaya, Desa Cicadas, Desa Mogana, Desa Kadubungbang, Desa Cikupa, Desa Cigarunggung, dan Desa Karang Tanjung, serta Forum Pemberdayaan Masyarakat Pemanfaatan Mata Air Cilembur (FPM-PMAC).

Bagi ketiga sektor di atas, permasalahan ketidakterpenuhan akses air bersih bagi sebagian masyarakat disebabkan oleh berbagai faktor. Pihak pemerintah mendefinisikan persoalan ini dengan memberikan argumentasi terkait kesulitan 
air baku yang didapatkan sebagai air bersih (PDAM Kabupaten Pandeglang, 2018). Argumentasi ini disebabkan oleh beberapa hal. Pertama, kendala geografis yang dihadapi oleh masyarakat (Yana, 2018; PDAM Kabupaten Pandeglang, 2018; Safutru, 2018; Setiadi, 2018). Kondisi ini termasuk kontur Kab. Pandeglang yang tidak rata dan daerahnya yang terpencar, sehingga membutuhkan medan tempuh yang cukup jauh dan memakan biaya cukup banyak (Safitri, 2018). Kedua, kapasitas idle capacity yang sudah maksimal dan tidak dapat ditambah lagi PDAM Kabupaten Pandeglang, 2018). Ketiga, minimnya penyediaan infrastruktur penunjangseperti jalan, jembatan, dan rumah layak huni-yang menjadi salah satu penyebab ketidakterpenuhan akses air bersih masyarakat (Emon, 2018; Asep, 2018).

Masyarakat sipil melihat permasalahan dengan kerangka yang cukup serupa, terutama terkait keterbatasan, jika bukan ketiadaan, air baku yang dapat mereka gunakan sebagai air bersih. Hal ini disebabkan oleh beberapa hal. Pertama, kendala geografis yang tidak memungkinkan mereka untuk mendapatkan air, termasuk posisi warga yang jauh atau lebih tinggi dari mata air sehingga terlalu menanjak untuk mengaliri air, kontur tanah yang penuh dengan batu sehingga sulit untuk membuat sumur bor (Yana, 2018), serta penuhnya tanaman kelapa sawit yang membuat penyimpanan sumber air menjadi sulit (Emon, 2018). Kedua, tidak adanya fasilitas saluran air yang diberikan oleh pemerintah untuk mereka mengalirkan air bersih. Ketiga, tarif air bersih dianggap memberatkan, sehingga tidak ada pilihan penyedia jasa lain yang lebih murah selain sektor privat (Madini, 2018; Lilis, 2018). Keempat, musim kemarau panjang yang menyebabkan surutnya mata air yang ada (Jajang, 2018; Mumun, 2018; Asep, 2018; Hidayat, 2018, Safitri, 2018; Yana, 2018). Pada kondisi ini, masyarakat mengeluh karena tidak adanya keterlibatan masyarakat dalam menentukan tarif air bersih dan dalam mendorong inisiatif-inisiatif pengelolaan yang diakui oleh pemerintah.

Sektor privat turut melihat keterbatasan air baku yang dimiliki masyarakat sebagai penyebab ketiadaan akses air bersih. Dalam kondisi ini, sektor privat hadir untuk menambal ketiadaan tersebut dengan membuat depot air minum dan mengirimkan truk tangki ke daerah-daerah yang membutuhkan air bersih (Asep, 2018; Muhadi, 2018). Tarif air yang harus dibayar oleh warga cukup beragam, bergantung pada profit yang diinginkan dan modal yang digunakan oleh sektor privat dalam mendistribusikan air sebagai barang ekonomi. Warga tidak memiliki ruang dan tidak memiliki posisi tawar yang tinggi untuk turut menentukan tarif tersebut. 
Baik pemerintah maupun masyarakat menggunakan argumentasi serupa dalam merespons ketidakterpenuhan akses air bersih masyarakat: keterbatasan air baku. Keterbatasan ini menjadi narasi yang digunakan oleh ketiga pemangku kepentingan. Meski demikian, perlu dipahami bahwa keterbatasan air baku dapat diisi dan didominasi oleh makna yang berbeda-beda. Ada saat di mana 'keterbatasan air baku' identik dengan 'ketiadaan idle capacity', danada masa di mana ia identik dengan 'keterbatasan kontur geografis' atau 'minimnya penyediaan infrastruktur penunjang'.

Pada kondisi ini, terdapat berbagai 'respons' yang diambil oleh ketiga sektor dalam menyiasati keterbatasan tersebut. Tulisan ini berargumen bahwa 'respons' yang ketiga sektor ambil dalam mengisi 'keterbatasan air baku' bersifat politis dan mudah berubah dibandingkan dengan narasi-narasi lain yang secara alamiah sulit diubah dan apolitis. Kontestasi paling menonjol ada pada dimensi respons atau tanggapan atas kondisi keterbatasan yang ada, di mana masing-masing sektoryang menyepakati 'keterbatasan air bersih' sebagai sebuah 'nodal point' dan dapat diterima secara kolektif-berupaya untuk mengisi makna dari 'nodal point' tersebut melalui respons-respons yang diambil. Dalam arti lain, terdapat kontestasi narasi terkait respons atas keterbatasan air baku. Hal ini mencakup bentuk pengelolaan yang diambil tiap sektor sebagai upaya untuk menyiasati keterbatasan tersebut.

\subsubsection{Malang}

Pemangku kepentingan yang terlibat dalam isu pemenuhan akses air bersih di Kabupaten Malang dapat dikelompokkan, setidaknya, ke dalam tiga sektor: pemerintah, swasta, dan masyarakat.

Di sektor pemerintah setingkat Kabupaten terdiri atas beberapa aktor seperti Dinas Perumahan, Kawasan Permukiman dan Cipta Karya (DPKPCK), Dinas Lingkungan Hidup (DLH), Badan Perencanaan Pembangunan Daerah (Bappeda), Dinas Kesehatan (Dinkes), Perusahaan Daerah Air Minum (PDAM). Selain itu, aktor seperti Pemerintah Desa dan Lembaga Pemberdayaan Masyarakat Desa (LPMD) juga secara tidak langsung terlibat dalam proses pengelolaan air di daerahnya. DPKPCK bertugas mengatur penyediaan air bersih di kawasan pedesaan yang tidak dilayani oleh PDAM, menyusun regulasi dan masterplan pelayanan air minum, mengembangkan prasarana, serta membina kelompok penyedia air minum berbasis masyarakat. DLH bertugas melestarikan ketersediaan sumber-sumber 
air baku di wilayah yang dikelola PDAM maupun masyarakat pedesaan. Bappeda berperan dalam melakukan distribusi tugas dari para pemangku kepentingan di isu air dan bersama-sama dengan DPKPCK mendesain masterplan. Dinkes berfungsi mengawasi kualitas air supaya sesuai dengan parameter kesehatan yang ditentukan. Sementara PDAM, selaku entitas semi-swasta, berperan sebagai operator dalam melayani kebutuhan air minum masyarakat.

Secara garis besar, aktor-aktor dalam sektor pemerintah mempersepsikan bahwa masalah keterbatasan pemenuhan akses air bersih disebabkan oleh dua hal utama. Pertama, kontur geografis di wilayah selatan Kabupaten Malangyang memiliki jumlah sumber air yang relatif lebih sedikit dibandingkan di wilayah utara-mengakibatkan keterbatasan air baku. Sebagai konsekuensinya, daerah pedesaan yang tidak memiliki dan/atau jauh dari sumber air kesulitan memperoleh pasokan air bersih. Kedua, lemahnya manajemen pengelolaan air yang melibatkan banyak aktor. Kelemahan manajemen tersebut disebabkan oleh faktor-faktor seperti perbedaan dalam mempersepsikan parameter 'akses', cakupan tanggung jawab yang tumpang tindih, dan sistem data yang belum tersinkronisasi.

Di sektor swasta, aktor yang keterlibatannya dominan adalah penyedia tangki air yang memasarkan air bersih ke daerah-daerah yang belum dijangkau oleh pelayanan PDAM maupun HIPPAM. Para penyedia tangki air lokal-di antaranya perusahaan milik perseorangan dengan merk Tirta Sumawe, AD, dan Padi Mas-juga melihat bahwa kontur geografis menyebabkan tidak meratanya ketersediaan air di daerah Kabupaten Malang. Alhasil, mereka mengambil air di sumber-sumber air dan mendistribusikannya ke daerah yang krisis air. Harga yang dipatok untuk satu tangki berisi lima kubik air adalah bekisar 150.000 rupiah.

Sementara itu, sektor masyarakat yang bergerak di bidang penyediaan air bersih adalah HIPPAM-HIPPAM yang tersebar di berbagai desa di wilayah Kabupaten Malang. HIPPAM tersusun atas elemen masyarakat yang berfungsi merencanakan, mengelola, dan menjalankan sistem penyediaan air bersih di wilayah operasionalnya. Relatif serupa dengan sektor pemerintah, aktor-aktor pegiat HIPPAM beranggapan bahwa terdapat dua masalah yang menyebabkan suatu daerah mengalami krisis air. Pertama, kontur geografis wilayah yang jauh dari sumber dan tidak memungkinkan pipanisasi. Kedua, kelemahan manajemen pengelolaan HIPPAM yang disebabkan oleh kurang harmonisnya koordinasi lintas aktor serta buruknya sistem kelembagaan, keuangan, dan teknis. 
Pada titik ini, narasi 'kontur geografis' menjadi narasi dominan yang samasama digunakan oleh berbagai pemangku kepentingan di ketiga sektor untuk mempersepsikan masalah ketidakterpenuhan akses air bersih bagi masyarakat di Kabupaten Malang. Kendati demikian, respons yang ditempuh oleh masing-masing pemangku kepentingan dimaknai dengan cara yang berbeda-beda. Relatif serupa dengan temuan di Pandeglang, 'respons' yang diambil oleh ketiga sektor dalam mengatasi permasalahan 'kontur geografis' bersifat politis dan memungkinkan untuk diisi oleh ide yang berbeda-beda dan saling berkontestasi. Berangkat dari pemahaman ini, masalah 'kontur geografis' dapat dimengerti sebagai suatu 'nodal point', yakni titik tempat terjadinya praktik artikulasi untuk menetapkan makna secara parsial dan mengupayakan agar masalah tersebut tampak alamiah. Dalam kata lain, terdapat kontestasi narasi terkait respons atas masalah kontur geografis. Respons ini mencakup variasi bentuk pengelolaan yang diambil masing-masing sektor dalam menyiasati masalah yang mereka persepsikan.

\section{Hasil dan Analisis}

Tulisan ini berargumen bahwa terdapat dua narasi antagonistik yang saling berkontestasi untuk mengisi diskursus respons atas 'masalah kontur geografis' di Kab. Malang dan 'keterbatasan air baku' di Kab. Pandeglang, yakni 'pengelolaan air secara top-down' selaku narasi hegemonik dan 'pengelolaan air secara bottom-up' selaku narasi kontra-hegemonik.

\subsection{Narasi Hegemonik: Analisis Pengelolaan Top-down}

Pada narasi pengelolaan air secara top-down, para aktor sepakat untuk melihat keterbatasan air baku sebagai sebuah permasalahan, namun mengambil respons dengan sedikit ruang partisipasi bagi kelompok-kelompok di pedesaan yang memiliki kesulitan mengakses air bersih.

Di Pandeglang, narasi ini diisi oleh berbagai respons yang berkaitan dengan kapasitas masyarakat, termasuk rendahnya kesadaran masyarakat untuk memiliki air bersih, sifat konsumtif masyarakat (Setiadi, 2018), cara pandang terkait pengelolaan yang sangat didominasi oleh penggunaan 'sistem cacing' dan sulit diubah, serta tingkat pengetahuan masyarakat dalam pengelolaan air yang sangat minim (Hidayat, 2018). Selain itu, terdapat benturan dengan masyarakat terkait kepemilikan mata air-sumber-sumber air yang melimpah tidak dapat 
digunakan karena tidak adanya persetujuan dari masyarakat setempat (PDAM Kabupaten Pandeglang, 2018). Narasi ini melihat upaya dari masyarakat untuk melindungi sumber air mereka sebagai suatu kendala atau faktor penghambat bagi distribusi air ke daerah-daerah lain, mengingat pendistribusian ini adalah program pemerintah yang didorong untuk memenuhi target 100-0-100 di tingkat nasional. Pada titik ini, problematisasi yang digunakan oleh narasi ini mendorong adanya perubahan dari atas-dari program-program pemerintah yang disusun untuk menyiasati kelemahan yang dimiliki masyarakat sipil dalam tata kelola air.

Narasi dominan ini dikelola dan dinormalisasi melalui proyek hegemonik yang melibatkan berbagai upaya. Upaya ini dapat dipahami sebagai praktik artikulasi yang berupaya menciptakan dan mempertahankan narasi hegemonik agar diterima secara alamiah oleh masyarakat umum. Pertama, adanya upaya inventarisasi atau pendataan cakupan air dan aspek-aspek lain yang berkaitan dengan air, dengan pemerintah sebagai pelaksana utamanya (Hidayat, 2018). Pada upaya ini, terdapat risiko untuk menginventarisasi pemenuhan akses berdasarkan bentuk akses yang dipahami secara sepihak oleh pemerintah, dan mengesampingkan bentuk-bentuk inisiatif lain dari masyarakat yang juga dilakukan untuk mendapatkan akses, namun tidak dapat dikategorisasi ke dalam istilah-istilah ilmiah dan formal seperti yang digunakan oleh pemerintah sebagai standar acuan.

Kedua, adanya program 100-0-100-100 persen akses air minum, 0 persen pemukiman kumuh, dan 100 persen fasilitas sanitasi serta drainase di seluruh wilayah Indonesia-yang dicetuskan oleh Kementerian pekerjaan Umum dan Perumahan Rakyat (PUPR) di tingkat nasional dan diserahkan pada pemerintah daerah sebagai penanggung jawab (PDAM Kabupaten Pandeglang, 2018). Program ini masuk ke dalam RPJMN (2014-2019) dengan target pencapaian 100\% di 2019. Dengan tenggat tersebut, pemerintah daerah terdesak untuk mendorong keberhasilan program dengan mendorong program-program atas. Hal ini, pada titik tertentu, membuat pencapaiannya ada di tingkat kuantitatif saja dan tidak mencakup kualitas yang memadai. Program ini juga mendorong pemerintah untuk mengesampingkan metode-metode yang lebih demokratis dalam mewujudkan 100 persen air bersih bagi masyarakat. Di samping itu, program Kota Tanpa Kumuh (Kotaku) di Kab. Pandeglang (Hidayat, 2018) juga mendorong pemerintah untuk melakukan pendekatan top-down untuk mencapai target. Program ini mencakup pembangunan fisik, di antaranya bangunan paving-block, drainase, dan Sarana Air Bersih (SAB). 
Ketiga, pihak pemerintah berupaya untuk mengkoordinasikan kegiatan pengelolaan di bawah Bappeda Kab. Pandeglang sebagai sektor terdepan (PDAM Kabupaten Pandeglang, 2018), juga mengintegrasikan pengelolaan air minum ke dalam BUMDes (Safitri, 2018; Hidayat, 2018; PDAM Kabupaten Pandeglang, 2018). Dengan cara ini, diharapkan tiap desa memiliki sarana air minum yang dikelola secara mandiri dan dapat memperoleh pendapatan asli desa dengan menarik tagihan air. Pemerintah juga membuat mekanisme koordinasi antara dinas dan juga kerja sama dengan BPBD Kab. Pandeglang untuk melakukan pengiriman bantuan ketika kekeringan datang (PDAM Kabupaten Pandeglang, 2018). Di samping itu, pemerintah turut mendorong PAMSIMAS yang didampingi secara aktif oleh pemerintah serta memberikan bantuan bagi program irigasi dan pipa-pipa saluran air (Safitri, 2018; Mumun, 2018). Desa-desa yang mendapatkan hibah PAMSIMAS ditentukan oleh tim Panitia Kemitraan (Pakem) yang dipimpin oleh Bappeda Kab. Pandeglang. Karenanya, PAMSIMAS hanya dapat diakses oleh masyarakat di desa yang mampu menyusun proposal pengajuan program PAMSIMAS dengan baik dan memiliki stok sumber air untuk dikelola lebih jauh. Daerah-daerah tanpa sumber daya air tidak dapat terlibat dalam kompetisi pemilihan desa tersebut.

Keempat, pemerintah mendorong adanya penggunaan air bersih yang sudah melalui pengujian kualitas air secara ilmiah dan memenuhi baku mutu dari Dinas Kesehatan. Tanpa adanya pemeriksaan laboratorium yang membutuhkan sejumlah dana, mata air tidak akan dianggap sebagai sumber yang relevan sebagai air bersih. Pemerintah berupaya untuk menawarkan proses pengujian pada beberapa depot, meski demikian tidak ada data yang sistematis terhadap depot-depot yang sudah dirangkul oleh pihak Dinas Kesehatan Kab. Pandeglang. Narasi ini mendorong masyarakat untuk melihat uji kualitas air sebagai sesuatu yang mutlak dan menghilangkan imajinasi alternatif pengelolaan air yang tidak perlu menggunakan uji kualitas tersebut. Hal ini dilihat dari beberapa metode yang masyarakat gunakan dalam pengelolaan, yakni penggunaan 'saluran cacing' dan tadah hujan. Bagi pemerintah, ketiadaan uji laboratorium atas kedua bentuk pengelolaan ini membuat posisinya lemah sebagai air baku dan harus digantikan dengan sistem yang ada di bawah Dinas Kesehatan.

Kelima, aspirasi yang muncul dari sektor privat serupa dengan narasi ini. Dalam kondisi keterbatasan air baku, respons yang diambil untuk menyiasati permasalahan tersebut adalah dengan mendorong masyarakat melakukan usaha 
depot air minum. Pihak swasta melakukan upaya untuk mencari pasar dengan mengisi celah-celah ketiadaan air baku yang dihadapi oleh masyarakat (Asep, 2018; Muhadi, 2018). Mereka juga turut mendorong adanya retribusi pada pemerintah untuk seluruh usaha depot air agar dapat melakukan pengecekan berkala terkait kualitas air, sehingga dapat memberi kepercayaan lebih pada masyarakat untuk menggunakan jasa dari sektor tersebut. Mereka menetapkan tarif sebesar Rp 150.000,- hingga Rp 600.000,- untuk mengirimkan air ke depot di berbagai daerah. Selain itu, mereka aktif membayar Rp 70.000,- kepada pihak kepolisian setempat sebagai biaya keamanan di jalan ketika mengantar truk tangki, membuat paguyuban khusus untuk pemilih truk tangki dan depot air minum, hingga membuat perjanjian kerja sama dengan depot tersebut. Proyek-proyek ini turut mendorong masyarakat untuk beralih ke sistem pasar dalam menyiasati keterbatasan air baku yang dialami, dan membuat masyarakat tidak berkeinginan melakukan pengelolaan mandiri yang dapat menguntungkan mereka secara langsung.

Keenam, hal serupa ditemukan dalam aspirasi yang dibawa oleh masyarakat. Ketika kekeringan datang dan sumber air habis, mereka cenderung untuk menunggu bantuan pipa dan truk tangki yang didistribusikan oleh pemerintah (Lilis, 2018). Hal ini termasuk bantuan pengeboran sumber air yang membutuhkan dana cukup besar (Mulyana, 2018). Di sisi lain, sebagian masyarakat tidak mengeluh atas tarif air yang semakin mahal dan menerima besaran tarif tersebut sebagai sesuatu yang wajar (Lilis, 2018; Yana, 2018; Madini, 2018). Masyarakat, pada titik ini, tidak memiliki imajinasi untuk melakukan pengelolaan secara swadaya dan memilih untuk terlibat dalam aturan main, baik pemerintah maupun pihak swasta.

Di Malang, aktor-aktor yang memiliki aspirasi untuk melakukan pengelolaan air secara top-down sama-sama mempersepsikan kontur geografis Kabupaten Malang sebagai masalah utama. Akan tetapi respons yang diambil untuk menyiasati masalah tersebut cenderung memberi ruang partisipasi yang sedikit bagi masyarakat. Narasi pengelolaan top-down ini diisi dengan berbagai persepsi bahwa akses air hanya akan optimal apabila dipenuhi oleh aktor-aktor yang tingkatnya di atas masyarakat, seperti entitas pemerintah dan swasta. Contoh persepsi tersebut yakni bahwa: penyediaan akses air merupakan tanggung jawab yang harus diemban pemerintah; kelompok penyedia air berbasis masyarakat tidak mampu memenuhi standar kualitas air yang baik; masyarakat merupakan kalangan 'awam' yang sulit diberi penjelasan tentang manajemen pemenuhan air. Narasi ini juga melihat bahwa partisipasi masyarakat dalam 
upaya memenuhi akses air merupakan hal yang bersifat menyaingi dan mengancam keberlangsungan aktor-aktor pelaku mekanisme top-down, salah satunya PDAM.

Narasi top-down ini dinormalisasi dan dipertahankan melalui proyek hegemonik yang diwujudkan dalam berbagai upaya-yang disebut sebagai praktik artikulasi-untuk membuat narasinya dianggap alamiah dan diterima oleh khalayak. Terdapat lima upaya proyek hegemonik yang dapat diidentifikasi di Kabupaten Malang.

Pertama, program nasional 100-0-100 oleh PUPR yang diturunkan ke tingkat daerah. Program ini mendorong pemerintah daerah, seperti DPKPCK dan PDAM, untuk mengupayakan pemenuhan akses air berdasarkan persentase target yang ditentukan. Alhasil, aktor-aktor pemerintah lah yang melakukan langkahlangkah dari atas untuk menyiasati masalah kontur geografis maupun merancang tata kelola air agar dapat memenuhi target 100-0-100. Program ini kemudian diejawantahkan ke dalam program masing-masing aktor. PDAM misalnya, dengan berpegangan pada target 100-0-100, berusaha mendaftar ke berbagai hibah pemasangan Sambungan Rumah (SR) untuk Masyarakat Berpenghasilan Rendah (MBR). Namun, hibah MBR ini juga dilandasi oleh kebutuhan untuk menambah pelanggan sebagai salah satu strategi keberlangsungan perusahaan. Di tahun 2016, PDAM mengikuti hibah pemasangan 8.000 SR. Dari 2015 hingga 2018, PDAM telah mengikuti program hibah yang mampu menambah pelanggan sebanyak kurang lebih 18.230 pelanggan. Sedangkan sejak 2011, total hibah yang telah diterima sejumlah lima program (Hadi, 2018). Kebutuhan untuk menambah pelanggan MBR ini pada titik tertentu mendorong PDAM untuk masuk ke wilayah pedesaan yang notabene tidak seharusnya menjadi cakupan wilayah layanan PDAM Kabupaten Malang.

Kedua, narasi pengelolaan top-down banyak diisi oleh aspirasi untuk menormalisasi standar kualitas dan harga air menurut parameter aktor tertentu. Aspirasi tersebut cenderung diwarnai dengan narasi yang menolak standar alternatif yang diadopsi oleh aktor masyarakat seperti HIPPAM. Sebagai ilustrasi, PDAM beranggapan bahwa Sistem Penyediaan Air Minum (SPAM) berbasis swadaya masyarakat tidak sesuai dengan aturan kesehatan yang memadai. Menurut PDAM, para pelaku HIPPAM tidak membayar retribusi untuk memperoleh SIPA (Surat Izin Pengambilan Air) yang melalui prosedur lingkungan hidup hingga Kementerian PUPR. Oleh karena itulah HIPPAM dapat menawarkan air dengan harga yang jauh lebih murah dibandingkan dengan PDAM. PDAM menilai bahwa HIPPAM tidak memenuhi kontrol kualitas, sehingga dapat berdampak bagi kesehatan konsumen 
(Hadi, 2018). Narasi semacam ini menunjukkan upaya aktor pemerintah untuk mengeksklusi narasi alternatif terkait kualitas dan harga air yang diajukan oleh aktor masyarakat.

Ketiga, pihak swasta, khususnya penyedia tangki air, berupaya merespons keterbatasan sumber air akibat masalah kontur geografis dengan cara menciptakan pasarnya sendiri. Mereka melihat krisis air sebagai peluang untuk menyuplai pasokan air dan mendorong permintaan masyarakat. Alhasil, para penyedia tangki air di wilayah krisis air di Kabupaten Malang, seperti di Desa Druju, Kecamatan Sumbermanjing Wetan, secara kontinyu menyuplai kebutuhan air pelanggan dengan harga yang relatif tinggi (Munir, 2018; Arini, 2018; Ana, 2018) dibandingkan dengan air PDAM maupun HIPPAM. Kendati demikian, masyarakat tetap membeli air tangki karena PDAM dan HIPPAM tidak mampu membangun pipanisasi di wilayah yang sumber airnya jauh. Di konteks ini, penyedia tangki mempertahankan respons yang bersifat top-down, termasuk menentukan harga secara sepihak untuk memperoleh profit.

Keempat, pihak swasta lain, yakni Indosiar selaku stasiun televisi swasta nasional, juga menerapkan solusi top-down untuk merespons krisis air di Desa Druju melalui program Corporate Social Responsibility (CSR). CSR Indosiar diwujudkan dalam bentuk pemberian sumur bor dan pompa, tanpa disertai pembangunan sistem sambungan untuk menyalurkan air sumur ke rumah-rumah warga. Kendati demikian, pemberian CSR tersebut dilakukan secara sepihak dan tidak didahului dengan musyawarah yang melibatkan seluruh komponen masyarakat. Akibatnya, setelah sumur bor tersebut terpasang, muncul beberapa kendala baru, seperti ketidakmampuan mendistribusikan air ke rumah-rumah warga, ketidakjelasan pihak yang akan bertanggung jawab untuk mengelola dan membayar iuran listrik, dan kecurigaan warga terhadap pemerintah desa yang dianggap menguasai aset CSR (Heri, 2018; Arini, 2018).

Ilustrasi dari seluruh upaya proyek hegemoni, baik di Pandeglang maupun di Malang, menunjukkan bahwa narasi pengelolaan secara top-down tidak memberikan ruang yang cukup bagi masyarakat untuk mengelola akses airnya sendiri. Meskipun pada derajat tertentu masyarakat turut dilibatkan dalam program-program tersebut, narasi hegemonik yang top-down cenderung menutup kesempatan bagi masyarakat untuk memajukan inisiatifnya sendiri. Bahkan narasi pengelolaan yang top-down dapat mempersempit peluang masyarakat 
untuk membayangkan skema maupun wacana alternatif tentang 'akses' air.

\subsection{Kontra-narasi Hegemonik: Pengelolaan Sumber Air Bottom-up}

Meski narasi yang berupaya mendorong aspirasi top-down menjadi hegemonik baik di level pemerintah, sektor privat, dan masyarakat, dislokasi muncul pada narasi tersebut sebagai sebuah keretakan yang memberi celah bagi narasi-narasi kontra-hegemonik. Dislokasi muncul ketika narasi top-down yang hegemonik tidak lagi mampu merespons kebaruan kondisi empiris masyarakat terkait kebutuhan air bersih. Dalam arti lain, narasi kontra-hegemonik adalah respons atas krisis yang muncul di dalam narasi top-down karena tidak mampu lagi menampung aspirasi-aspirasi masyarakat di lapangan yang membutuhkan akses air.

Di Pandeglang, narasi yang ada tidak mampu untuk menampung aspirasi dari masyarakat miskin yang terdesak untuk memenuhi kebutuhan air. Dorongan ini menguat seiring dengan meningkatnya jumlah penduduk yang membutuhkan air dan dengan minimnya keterlibatan masyarakat dalam pengelolaan dan penentuan tarif air bersih. Bantuan-bantuan dari atas, contohnya truk tangki pada masa kekeringan atau pipanisasi untuk mengalirkan air, tidak lagi dapat memenuhi kebutuhan hidup masyarakat sehari-hari. Hal ini mendorong kemunculan narasi baru dan alternatif yang dapat mengerangkai upaya masyarakat dalam memenuhi kebutuhannya atas air.

Narasi kontra-hegemonik muncul sebagai upaya untuk menjadikan masyarakat sebagai pelaku utama dan memberikan ruang serta posisi tawar bagi inisiatif-inisiatif pengelolaan yang dilakukan oleh masyarakat. Narasi ini juga menggarisbawahi kemampuan dan kesadaran masyarakat sebagai subjek yang melakukan pengaturan atas air. Hal ini diwujudkan dengan berbagai praktik artikulasi yang mendorong aspirasi pengelolaan dari bawah. Pertama, masyarakat mendorong upaya penataan sumber daya untuk dimanfaatkan oleh masyarakat sebaik mungkin. Hal ini termasuk upaya swadaya dalam mengelola jaringan pipa dan bambu untuk mengaliri air, serta mengumpulkan dana untuk biaya perawatan secara musyawarah (Mulyana, 2018; Mumun, 2018; Hidayat, 2018). Kedua, masyarakat memiliki aspirasi untuk memiliki sumur airnya sendiri sebagai syarat untuk menyiasati kebutuhan air bersih (Lilis, 2018). Sumur ini, kemudian, akan digunakan sebagai sumur bersamamenggunakan air pancuran dan pipa yang dikelola oleh masyarakat. Sebagian masyarakat sudah mengelola sumber air ini secara profesional-melalui kesepakatan ber- 
sama, pengumpulan iuran, dan menarik air dari gunung ke rumah masing-masing.

Ketiga, masyarakat berupaya untuk menolak berbagai permintaan sumber air dari pihak pemerintah atau pihak swasta (Setiadi, 2018; Rusli, 2018; Kamil, 2018). Hal ini dilakukan karena masyarakat takut pengelolaannya terganggu, terutama untuk pertanian dan jumlah debit air yang tersedia. Keempat, masyarakat berupaya membuat air kemasannya sendiri sebagai bentuk penataan sumber daya yang ada untuk dimanfaatkan oleh masyarakat sebaik mungkin (Amin, 2018). Hal ini menunjukkan bahwa masyarakat mendorong aspirasi untuk mengelola sendiri sumber airnya dan tidak melibatkan pihak luar. Kelima, program PAMSIMAS yang diinisiasi oleh pemerintah mendorong keterlibatan masyarakat secara aktif dan agar masyarakat melakukan upaya pengelolaan secara mandiri dan swadaya. Masyarakat dituntut untuk terlibat dalam berbagai permasalahan teknis.

Di konteks Kabupaten Malang, narasi kontra-hegemoni yang bersifat bottomup cenderung menekankan bahwa negara (pemerintah daerah) kurang memberikan kesempatan bagi masyarakat untuk mengelola sistem penyediaan airnya sendiri. Di sisi lain, narasi yang bottom-up secara dominan diisi oleh persepsi bahwa para penyedia air berbasis masyarakat berperan untuk mengisi celah yang muncul akibat ketidakmampuan pihak pemerintah dalam memenuhi akses air bersih di daerah pedesaan.

Pertama, masyarakat di Kabupaten Malang, dalam wadah asosiasi HIPPAM, mengupayakan pertukaran pengalaman dan pengetahuan melalui forum-forum informal yang biasa mereka sebut sebagai "cangkrukan" (bincang-bincang) yang bermanfaat. Kendati pertemuan asosiasi ini tidak dilakukan di bawah skema legal-formal, para pelaku HIPPAM merasa memperoleh manfaat dari adanya asosiasi tersebut (Muhammad, 2018; Djauhari, 2018). Dengan upaya tersebut, mereka berusaha memperkuat ikatan dan menyinkronkan narasi bottom-up.

Kedua, aktor masyarakat di Kabupaten Malang berusaha mengajukan narasi bottom-up melalui aspirasi untuk menjadi independen. Pada konteks HIPPAM di wilayah Sumber Maron misalnya, aktor masyarakat bersikukuh untuk memisahkan diri dari pihak pemerintah desa maupun Bumdes. Pada titik ini, masyarakat juga memiliki kekhawatiran bahwa pihak desa akan 'mencaplok' dan menghambat keberlangsungan HIPPAM (Muhammad, 2018; Staff Teknik HIPPAM Sumber Maron, 2018).

Ketiga, beberapa pelaku HIPPAM bahkan masuk ke wilayah yang terma- 
suk dalam jangkauan PDAM untuk 'menyaingi' layanan PDAM. HIPPAM memiliki kemudahan untuk menarik pelanggan PDAM agar beralih ke layanan HIPPAM berkat penerapan skema tarif air yang lebih murah dan narasi yang mengunggulkan rasa kepemilikan masyarakat terhadap sumber air di wilayahnya sendiri. Strategi penarikan pelanggan ini dijustifikasi dengan narasi 'pasar bebas', yakni membiarkan masyarakat yang memilih sendiri penyedia layanan air sesuai dengan minatnya ( $\mathrm{Mu}-$ hammad, 2018). Upaya ini mencoba memajukan narasi bahwa sistem penyediaan air berbasis masyarakat dinilai lebih sesuai dan diminati oleh masyarakat itu sendiri.

Keempat, aktor masyarakat berupaya untuk merebut narasi terkait standar kualitas air yang didominasi oleh pengelolaan secara top-down. HIPPAM di Sumber Maron misalnya, menekankan bahwa meskipun tarif airnya murah, air tersebut telah melalui serangkaian tes laboratorium dan disetujui oleh Dinkes (Muhammad, 2018; Staff Teknik HIPPAM Sumber Maron, 2018). Tidak dipungkiri bahwa belum semua HIPPAM di Kabupaten Malang telah melakukan standarisasi kesehatan secara rutin. Kendati demikian, upaya untuk memenuhi standar tersebut telah disadari dan ditempuh oleh para pelaku HIPPAM (Muhammad, 2018).

Pada titik ini, narasi bottom-up menjadi sebuah respons atas keterbatasan air baku yang berupaya memberikan makna spesifik: bahwa pengelolaan dan program terkait sumber air bersih harus ada di dalam kontrol masyarakat-pihak lain dapat terlibat sejauh tidak mengubah posisi masyarakat sebagai pelaku utama yang memiliki kemampuan dan kesadaran untuk melakukan pengelolaan air. Narasi ini mendorong masyarakat untuk mengutamakan musyawarah dan pengelolaan di level masyarakat sebagai upaya untuk menata air secara mandiri. Narasi ini juga mendorong adanya skema untuk mengatasi permasalahan kekeringan yang dihadapi oleh masyarakat. Narasi ini, karenanya, mendorong masyarakat untuk menggunakan pengetahuan dan inisiasinya yang sesuai dan kontekstual dengan kondisi empiris mereka, serta mereduksi imajinasi-imajinasi masyarakat yang mengandalkan pihak lain dalam memenuhi kebutuhan mereka atas air.

\subsection{Analisis}

Meski pada beberapa titik terdapat ruang di mana masyarakat dapat terlibat, program-program yang ada dalam proyek hegemonik top-down menunjukkan aspirasi program yang muncul dari atas. Masyarakat terlibat sebagai bagian dari upaya untuk memenuhi program yang sudah ada dan sudah ditentukan, namun 
tidak untuk mengusulkan program-program atau inisiatif baru yang memiliki potensi tidak sesuai dengan standar-standar pemerintah dan tidak relevan untuk dipertimbangkan. Narasi ini mengidentifikasi faktor penghambat dari sisi masyarakat dan mendorong agar masyarakat masuk ke dalam skema yang sudah ditentukan oleh pemerintah. Karenanya, narasi ini, pada titik terjauhnya, menciptakan ketergantungan masyarakat pada sistem-sistem yang dikelola di luar diri mereka.

Pada titik ini, narasi top-down menjadi sebuah respons atas keterbatasan air baku yang berupaya memberikan makna spesifik: bahwa pengelolaan dan program terkait sumber air bersih harus ada di dalam skema buatan pemerintah, meski masyarakat turut terlibat sebagai elemen di dalamnya. Narasi ini mendorong masyarakat untuk mengandalkan solusi dan skema-skema dari pemerintah maupun sektor privat sebagai upaya mengatasi keterbatasan air baku. Narasi ini, akibatnya, berupaya mengeliminasi imajinasi-imajinasi pengelolaan lain dari masyarakat. Narasi ini turut membuat ketergantungan pada sektor lain menjadi sebuah normalitas dan membuatnya janggal jika tidak dijalani. Alih-alih mendorong inisiatif agar berdaya, masyarakat dapat mempersepsikan ketiadaan peran sektor lain sebagai sebuah kesalahan yang harus dibenahi dan menjadi respons utama yang diambil. Narasi ini tidak hanya didorong secara eksklusif oleh pemerintah dan sektor privat, namun juga oleh masyarakat. Masyarakat sebagai pihak yang ingin diberdayakan, pada titik tertentu, turut menjadi pihak yang mendorong narasi top-down-membuat narasi tersebut langgeng dan menerima bahwa pengelolaan tetap harus dipegang oleh pihak pemerintah.

Tabel 1. Analisis Kontestasi Diskursus

\begin{tabular}{|c|c|c|}
\hline \multirow{3}{*}{$\begin{array}{l}\text { Sumber } \\
\text { permasalahan dari } \\
\text { akses yang minim }\end{array}$} & Narasi hegemonic & Narasi kontra-hegemoni \\
\hline & $\begin{array}{l}\text { Pandeglang. Keterbatasan air baku (ketiadaan idle-capacity } \\
\text { dan kontur geografis, ketiadaan fasilitas penunjang) }\end{array}$ & Pandeglang. Keterbatasan air baku (kontur geografis) \\
\hline & $\begin{array}{l}\text { Malang. Hambatan kontur geografis (jauh dari dan/atau tidak } \\
\text { memiliki sumber air) }\end{array}$ & $\begin{array}{l}\text { Malang. Hambatan kontur geografis (jauh dari dan/ } \\
\text { atau tidak memiliki sumber air) }\end{array}$ \\
\hline $\begin{array}{l}\text { Respons yang } \\
\text { diberikan }\end{array}$ & $\begin{array}{l}\text { Pengelolaan top down, minimnya pengetahuan dan kesadaran } \\
\text { masyarakat terkait pengelolaan air }\end{array}$ & $\begin{array}{l}\text { Pengelolaan bottom up, inisiasi pengelolaan yang diatur } \\
\text { secara mandiri oleh masyarakat }\end{array}$ \\
\hline Dasar inisiasi proyek & $\begin{array}{l}\text { Kerangka legal dan dokumen rencana pembangunan formal } \\
\text { yang dikeluarkan oleh pemerintah }\end{array}$ & $\begin{array}{l}\text { Kebutuhan untuk mendapatkan air bersih, inisiasi- } \\
\text { inisiasi berlandaskan kesepakatan musyawarah }\end{array}$ \\
\hline $\begin{array}{l}\text { Pelaku utama } \\
\text { pengelolaan }\end{array}$ & Pemerintah dan sektor privat & Masyarakat \\
\hline \multirow[t]{2}{*}{$\begin{array}{l}\text { Mekanisme yang } \\
\text { digunakan }\end{array}$} & $\begin{array}{l}\text { Pandeglang. Inventarisasi cakupan air dari atas, program } \\
\text { 100-0-100 dan Kotaku, integrasi BUMDes, pengujian ilmiah } \\
\text { kualitas air, penciptaan pasar depot air minum, penekanan } \\
\text { bantuan dari pemerintah, penerimaan tarif air yang mahal }\end{array}$ & $\begin{array}{l}\text { Pandeglang. Membuat air kemasan sendiri, } \\
\text { musyawarah dan pengumpulan iuran, pengelolaan } \\
\text { sumur bersama, penolakan terhadap pemerintah/ } \\
\text { pihak swasta }\end{array}$ \\
\hline & $\begin{array}{l}\text { Malang. Program 100-0-100 dan hibah SR untuk MBR, } \\
\text { menormalisasi standar kualitas air dan tarif air, penjualan } \\
\text { tangki air, pemberian CSR }\end{array}$ & $\begin{array}{l}\text { Malang. Pembuatan asosiasi HIPPAM, aspirasi untuk } \\
\text { independen, pengembangan layanan ke wilayah } \\
\text { cakupan PDAM, pemaknaan ulang standar kualitas air. }\end{array}$ \\
\hline
\end{tabular}


Meski demikian, pemilahan biner pada narasi hegemonik dan kontrahegemonik bukan sesuatu yang statis dan total hingga tidak dapat diubah. Pada kondisi struktural tertentu, masing-masing narasi berupaya mengapropriasi satu sama lain dan menjadikan yang lain tunduk pada dirinya sebagai upaya melakukan proyek hegemoni. Tiap aktor dapat menggunakan salah satu narasi pada masa berbeda, sehingga penggunaan sebuah narasi secara eksklusif oleh satu aktor menjadi tidak relevan. Dalam arti lain, tiap aktor dapat terpapar oleh berbagai narasi pada kondisi yang berbeda, sehingga analisis harus dilakukan terhadap narasi-narasi yang secara spesifik digunakan masyarakat pada waktu tertentu.

Kedua kutub narasi menciptakan spektrum yang membuat berbagai kekuatan sosial dalam masyarakat melakukan tarik menarik dalam mendefinisikan respons yang tepat untuk mengatasi keterbatasan air baku. Tarik menarik ini dilakukan oleh berbagai kekuatan sosial sebagai upaya mendorong proyek hegemoni dan kontra-hegemoni. Beberapa upaya dari kelompok yang mendorong narasi bottomup menunjukkan keberhasilan mereka dalam mengapropriasi narasi top-down.

Proyek kontra-hegemoni, karenanya, dapat ditemukan dan diinisiasi tidak hanya oleh kekuatan sosial yang terdiri dari masyarakat, namun juga dari pihak pemerintah dan kelompok-kelompok lain yang memiliki aspirasi serupa terkait manajemen air bersih. Hal ini menjadi penting mengingat, sejauh ini, masyarakat sendiri tidak memiliki kekuatan untuk mendorong adanya perubahan alokasi finansial pemerintah yang dapat menciptakan banyak ruang untuk memperbaiki fasilitas penunjang dan sumber mata air yang dapat memenuhi akses mereka atas air. Dalam arti lain, proyek kontra-hegemoni belum berhasil membuat jejaring ekuivalensi yang dapat mendorong narasi bottom-up dan mendorong terbukanya akses masyarakat pedesaan atas air. Pada kasus ini, proyek hegemoni dapat terhambat karena tiap aktor melihat masing-masing aktor secara terpisah dan menutup kemungkinan bagi sektor selain dirinya untuk terlibat dalam mendorong akses yang lebih luas. Proyek kontra-hegemoni perlu untuk mengidentifikasi keberadaan narasi yang diusungnya di tiap sektor pemangku kepentingan, dan mendorong kolaborasi lebih jauh berdasarkan pemilahan narasi tersebut. Mengingat karakter narasi yang saling tarik menarik antara proyek hegemoni dan proyek kontra-hegemoni, menjadi penting bagi berbagai pihak untuk secara fleksibel menentukan aliansi yang dimilikinya dalam mendorong proyek politik tersebut. 


\section{Kesimpulan}

Ketimpangan akses air bersih di kedua kabupaten terjadi karena terdapat kontestasi diskursus terkait respons yang diambil untuk menyiasati keterbatasan geografis dan keterbatasan air baku. Kontestasi ini berakibat pada keberadaan narasi kompetisi yang saling menjatuhkan di antara berbagai penyedia air bersih. Ketegangan yang muncul antar narasi membuat para pemangku kepentingan tidak bersepakat pada respons yang diambil untuk mengatasi permasalahan keterbatasan sumber air dan untuk memperluas akses masyarakat terhadap air bersih. Mereka berlomba-lomba untuk memenuhi kebutuhan air bersih di daerah yang sudah memiliki kapasitas dasar dan meninggalkan daerah yang tidak menguntungkan, jauh dari sumber air, dan memerlukan investasi yang besar. Sehingga, alih-alih bersepakat dan berjejaring mengupayakan daerah yang memang memiliki tantangan besar dalam pemenuhan air atau daerah rawan air, mereka berupaya untuk mengakumulasi keuntungan di daerah yang berpotensi menghasilkan keuntungan.

Diskursus pengelolaan top-down menjadi hegemonik, baik di Kab. Pandeglang maupun Kab. Malang. Pada diskursus ini, aktor sepakat untuk melihat keterbatasan air baku sebagai sebuah permasalahan, namun mengambil respons yang melibatkan sedikit ruang partisipasi bagi masyarakat. Narasi ini tidak semertamerta menghilangkan peran masyarakat, namun meletakkan aktivitas masyarakat di dalam skema dan program yang diinisiasi oleh pemerintah atau sektor privat. Narasi ini mendorong adanya perubahan dari atas-dari program-program pemerintah yang disusun untuk menyiasati kelemahan yang dimiliki masyarakat sipil dalam tata kelola air. Pada titik terjauh, narasi ini menghilangkan imajinasi yang dimiliki masyarakat untuk mengelola air secara mandiri dan dengan cara-cara alternatif yang mungkin muncul sesuai dengan kondisi empiris masyarakat. Di saat yang sama, proyek kontra-hegemoni menemukan relevansinya dalam situasi di mana narasi top-down tidak lagi mampu menampung aspirasi masyarakat terhadap air bersih. Pengelolaan bottom-up didorong sebagai alternatif pengelolaan yang diharapkan dapat memberi ruang bagi standar-standar yang diinisiasi oleh masyarakat terhadap air bersih dan menjadikan masyarakat mandiri dalam melakukan pengelolaan air.

Perlu digarisbawahi bahwa kedua diskursus yang berkontestasi tidak dapat dilekatkan secara eksklusif pada aktor tertentu. Dalam arti lain, analisis terhadap kekuatan sosial masyarakat yang menggunakan masing-masing narasi menjadi krusial untuk menentukan aliansi dalam mendorong proyek kontra- 
hegemoni. Kasus Pandeglang dan Malang menunjukkan bahwa pihak-pihak yang mendorong narasi kontra-hegemonik tidak berhasil membuat jejaring ekuivalensi ke pihak yang memiliki narasi sejenis. Akibatnya, tuntutan mereka bersifat parsial dan tidak menjadi proyek kontra-hegemoni yang berhasil. Kami menyarankan pihak-pihak yang mengupayakan narasi kontra hegemonik untuk lebih fleksibel dalam mencari aliansi dengan tidak menitikberatkan pada kontestasi biner antar aktor-aktor, seperti pemerintah vs masyarakat, masyarakat vs sektor privat, atau masyarakat vs pemerintah desa, namun berfokus pada kontestasi narasi yang dibawa oleh tiap aktor. Pada kondisi ini, penekanan pada narasi akan memudahkan koordinasi dan kolaborasi antar aktor dalam pemenuhan akses air bersih. Lebih jauh, pemerintah sebagai aktor yang memiliki berbagai program penyediaan air bersih untuk masyarakat perlu mengakui dan mengakomodasi diskursus dan inisiatif yang didorong oleh berbagai pihak. Dengan kata lain, program-program pemerintah yang bersifat mengintervensi kondisi krisis air bersih sebaiknya dapat dilakukan tanpa meniadakan diskursus dari masing-masing pemangku kepentingan.

Pertanyaannya kemudian adalah bagaimana pemerintah dapat mengakomodasi berbagai diskursus dari pemangku kepentingan di isu ini. Setidaknya terdapat dua cara yang tulisan ini rekomendasikan. Pertama, memperkuat upaya mandiri masyarakat dalam mengupayakan pemenuhan kebutuhan airnya. Belajar dari konteks Malang dan Pandeglang, beberapa usaha konkrit pemerintah yang dapat dilakukan untuk memperkuat upaya mandiri masyarakat dalam pemenuhan air adalah adalah pertama, mengikutsertakan berbagai komponen masyarakat di daerah krisis air dan yang belum memiliki himpunan/asosiasi pemenuhan air ke Pokja AMPL. Kedua, membantu pengadaan teknologi sederhana pengelolaan air seperti Pembangkit Listrik Tenaga Mikrohidro (PLTMH) dan elektrolisa air hujan. Ketiga, memberikan dukungan pendampingan pengelolaan air secara mandiri yang berorientasi pada keberlanjutan. Dengan kata lain, pendampingan harus memastikan masyarakat benar-benar bisa menjalankan pengelolaan airnya, tidak hanya didampingi dalam waktu yang singkat lalu ditinggalkan saat pengelolaannya belum mumpuni. Keempat, mengatur dan membuat regulasi sektor privat penyedia air, misalnya memberikan regulasi terkait standar kesehatan, subsidi tangki air bersih, atau mengatur mekanisme penentuan harga jual. Kelima, melibatkan jeja ring non-governmental organizations (NGOs) dan mengarusutamakan isu air dalam agenda mereka. Keenam, melibatkan peran universitas dan mengarusutamakan 
isu air di program-program KKN dan program pengabdian universitas lainnya. Kedua,mengalokasikan dana untuk menciptakan mekanisme atau program di daerah krisis air yang tidak memiliki sumber air baku. Beberapa upaya konkrit yang bisa dilakukan oleh pemerintah adalah pertama, menginisiasi program percepatan daerah yang akses airnya tertinggal. Kedua, memayungi upaya transfer teknologi dan pengetahuan antara daerah-daerah yang pengelolaan akses airnya baik dengan daerah-daerah krisis air Ketiga, membangun jaringan perpipaan untuk mengalirkan air di daerah yang terhambat kontur geografis.

\section{Referensi}

Banten, BPS. (2018). "Luas Wilayah Menurut Kabupaten/Kota di Provinsi Banten, 2016." BPS Banten, 25 April 2018. Diakses pada Juni 23, 2018. https://banten.bps.go.id/dynamictable/2018/04/25/192/luas-wilayah-menurut-kabupaten-kota-di-provinsi-banten-2016.html.

Bappenas (2017). Infografis Evaluasi Paruh Waktu RPJMN 2015-2019. Jakarta: Bappenas, 2017.

Bappenas. (2018). “Kejar Target 100 Persen Akses Air Minum dan Sanitasi di 2019, Bappenas Optimalkan DAK dan Dana Desa.” Bappenas, November 7, 2017. Diakses pada Juni 23, 2018.https://www.bappenas.go.id/id/berita-dan-siaran-pers/kejar-target-100-persen-akses-air-minum-dan-sanitasi-layak-di-2019-bappenas-optimalkan-dak-dan-dana-desa/.

Hiariej, Eric. , (2017). "Politik Jokowi: Politik Pasca-Klientelisme dalam Rantai Ekuivalensi yang Rapuh.” Prisma 36, 2017: 127-147.

Indonesia, Unicef. (2012). Ringkasan Kajian: Air Bersih, Sanitasi \& Kebersihan. Jakarta: Unicef.

Jorgensen, Marianne, dan Louise J. Phillips. (2002). Discourse Analysis as Theory and Method. London: SAGE Publications Ltd.

Kesehatan, Kementrian. (2017). "Daftar Kabupaten/Desa STBM (Pamsimas III) Tahun Anggaran 2017.” Kementrian Kesehatan.” Kementrian Kesehatan, 2017. http://www.depkes.go.id/resources/download/info-terkini/permenkes $\% 20$ 71\%20tahun\%202016/2.\%20Daftar\%20Kabupaten\%20dan\%20Desa\%20 Pamsimas\%20III\%20\%20Tahun\%202017.pdf.

Laclau, Ernesto. (1990). New Reflection on the Revolution of Our Time. London: Verso.

Laclau, Ernesto, dan Chantal Mouffe. (1985). Hegemony and Socialist Strategy: Towards a Radical Democratic Politics. London: Verso.

Malang, BPS Kabupaten. (2017). Kabupaten Malang Dalam Angka 2017. Kabupaten Malang: BPS Kabupaten Malang.

Malang, DPKPCK Kabupaten. (2017). Perubahan Renstra Dinas Perumahan Kawasan Permukiman dan Cipta Karya Kabupaten Malang tahun 2016-2021. Kabupaten Malang: DPKPCK Kabupaten Malang. 
Malang, PDAM Kabupaten. (2018). “Presentasi Kunjungan Kerja PDAM Kabupaten Sukabumi”. Presentasi pada kunjungan kerja PDAM Kabupaten Sukabumi, Malang.

Masduqi, Ali, Noor Endah, Eddy S. Soedjono, dan Wahyono Hadi. (2007). "Capaian Pelayanan Air Bersih Perdesaan Sesuai Millenium Development Goals-Studi Kasus di Wilayah DAS Brantas". Jurnal Purifikasi 8, no. 2, 2007: 115-120.

Mouffe, Chantal. (2005). On the Political. New York: Routledge.

Noviyanti, Evlina, dan Rulli Pratiwi Setiawan. (2014). "Penyediaan Air Bersih Pada Kawasan Rawan Air Bersih di Pesisir Utara Lamongan”. Tata Loka 16, no. 2, 2014: 116-132.

Pandeglang, BPS Kabupaten. (2015). Kabupaten Pandeglang dalam Angka 2015. Pandeglang: BPS Kabupaten Pandeglang.

Pandeglang, BPS Kabupaten. (2017). Kabupaten Pandeglang dalam Angka 2017. Pandeglang: BPS Kabupaten Pandeglang.

Pandeglang, Kabupaten dan Institut Teknologi Bandung. Dinas Perumahan Kawasan Permukiman dan Pertanahan Kabupaten Pandeglang dan Lembaga Penelitian dan Pengabdian kepada Masyarakat Institut Teknologi Bandung.

Pandeglang. (2017). Penyusunan Rencana Induk Sistem Penyediaan Air Minum Kabupaten Pandeglang 2018-2032: Laporan Akhir 2017. Pandeglang: Dinas Perumahan Kawasan Permukiman dan Pertanahan Kabupaten Pandeglang.

Robinson, Andy. (2005). "Indonesia National Program for Community Water Supply and Sanitation Services: Improving Hygiene \& Sanitation Behavior and Services”. World Bank. December, 2005. Diakses pada 26 Juni 2018. http://siteresources.worldbank.org/INTWSS/Resources/Indonesia.pdf.

Soebagyo, Lyla Rachmaningtyas, Deni Kusumawardani, dan Rachma Bhakti Utami. (2013). "Akses Terhadap Air Perpipaan di Indonesia: Kajian Sosio-Ekonomi." Jurnal Ekonomi dan Bisnis, 2013: 38-46.

Sukartini, Ni Made, dan Samsubar Saleh. (2016). "Akses Air Bersih di Indonesia." Jurnal Ekonomi Kuantitatif Terapan 9, no. 2, 2016: 89-98.

Timur, BPS Jawa. (2016). "Luas Wilayah Menurut Kabupaten/Kota di Provinsi Jawa Timur, 2016.” BPS Jawa Timur, Agustus 28, 2017. Diakses pada Juni 23, 2018. https://jatim.bps.go.id/dynamictable/2017/08/28/46/luas-wilayah-menurutkabupaten-kota-di-provinsi-jawa-timur-2016.html.

Utama, Chandra. (2010). "Peningkatan Akses Air Bersih Bagi Seluruh Masyarakat". Jurnal Administrasi Bisnis 6, no. 2 (2010): 146-159.

\section{Wawancara}

Amin (Ketua Forum Pemberdayaan Masyarakat Pemanfaatan Mata Air Cilembur (FPM-PMAC)), wawancara oleh Tadzkia Nurshafira, Marselinus Saka, dan Maharani Hapsari, Pandeglang, 8 April 2018.

Ana (warga Dusun Sumbernanas), wawancara oleh Husna Yuni Wulansari dan Taradhinta Suryandari, Malang, 4 April 2018.

Arini (warga Dusun Sumbernanas), wawancara oleh Husna Yuni Wulansari dan Taradhinta Suryandari, Malang, 4 April 2018 
Asep (warga Desa Girijaya), wawancara oleh Maharani Hapsari, Marselinus Saka dan Tadzkia Nurshafira, Pandeglang, 5 April 2018.

Djauhari (Fasilitator PAMSIMAS Kabupaten Malang), wawancara oleh Husna Yuni Wulansari dan Taradhinta Suryandari, Malang, 3 April 2018.

Emon (warga Kecamatan Sindangresmi), wawancara oleh Maharani Hapsari, Marselinus Saka dan Tadzkia Nurshafira, Pandeglang, 3 April 2018.

Heri (Kepala Dusun Sumbernanas), wawancara oleh Husna Yuni Wulansari dan Taradhinta Suryandari, Malang, 4 April 2018.

Hidayat (Kepala DPKPP), wawancara oleh Maharani Hapsari, Marselinus Saka dan Tadzkia Nurshafira, Pandeglang, 3 April 2018.

Jajang (Warga Desa Girijaya), wawancara oleh Tadzkia Nurshafira dan Marselinus Saka, Pandeglang, 5 April 2018.

Kamil (Warga Desa Cikoromoy, Pandeglang), wawancara oleh Tadzkia Nurshafira dan Marselinus Saka, Pandeglang, 7 April 2018.

Lilis (warga Desa Cicadas), wawancara oleh Tadzkia Nurshafira dan Marselinus Saka, Pandeglang, 8 April 2018.

Madini (warga Desa Cikupa), wawancara oleh Tadzkia Nurshafira, Pandeglang, 3 April 2018.

Muhadi (pemilik depot air minum di Pandeglang), wawancara oleh Tadzkia Nurshafira dan Marselinus Saka, Pandeglang, 6 April 2018.

Mulyana (Ketua RW 7 Desa Cicadas), wawancara oleh Tadzkia Nurshafira dan Marselinus Saka, Pandeglang, 8 April 2018.

Muhammad, Sayyid (Ketua Asosiasi HIPPAM Kabupaten Malang), wawancara oleh Maharani Hapsari, Husna Yuni Wulansari dan Taradhinta Suryandari, Malang, 30 Maret 2018.

Mumun (warga Desa Mogana), wawancara oleh Tadzkia Nurshafira dan Marselinus Saka, Pandeglang, 10 April 2018.

Munir (Ketua Lembaga Pemberdayaan Masyarakat Desa Druju), wawancara oleh Husna Yuni Wulansari dan Taradhinta Suryandari, Malang, 1 April 2018.

Pandeglang, PDAM Kabupaten. wawancara oleh Maharani Hapsari, Marselinus Saka dan Tadzkia Nurshafira, Pandeglang, 4 April 2018.

Rusli (Ketua RW 4 Desa Karangtanjung, Pandeglang), wawancara oleh Marselinus Saka, Pandeglang, 9 April 2018.

Safitri (Ketua Fasilitator PAMSIMAS Kab. Pandeglang), wawancara oleh Tadzkia Nurshafira, Pandeglang, 9 April 2018.

Setiadi (Kepala Desa Girijaya), wawancara oleh Maharani Hapsari, Marselinus Saka dan Tadzkia Nurshafira, Pandeglang, 5 April 2018.

Sidharta (Kasi Pengembangan Prasarana Air Minum, Dinas Perumahan, Kawasan Permukiman, dan Cipta Karya Kabupaten Malang), wawancara oleh Maharani Hapsari, Husna Yuni Wulansari, dan Taradhinta Suryandari, Malang, 28 Maret 2018.

Staff teknik HIPPAM Sumber Maron, wawancara oleh Maharani Hapsari, Husna Yuni Wulansari dan Taradhinta Suryandari, Malang, 28 Maret 2018.

Syamsul Hadi (Direktur Utama PDAM Kabupaten Malang), wawancara oleh Maha- 
rani Hapsari, Husna Yuni Wulansari, dan Taradhinta Suryandari, Malang, 29 Maret 2018.

Wijaya, Hadi (Staff seksi NRW PDAM Kabupaten Malang), wawancara wawancara oleh Maharani Hapsari, Husna Yuni Wulansari, dan Taradhinta Suryandari, Malang, 28 Maret 2018.

Yana (Ketua RT 2 Desa Cicadas), wawancara oleh Tadzkia Nurshafira dan Marselinus Saka, Pandeglang, 6 April 2018. 